\title{
Greenhouse gas emissions along a peat swamp forest degradation gradient in the Peruvian Amazon: soil moisture and palm roots effects
}

\author{
Jeffrey van Lent ${ }^{1,2,3} \cdot$ Kristell Hergoualc' ${ }^{1}{ }^{1}$ \\ Louis Verchot ${ }^{4}$ - Oene Oenema ${ }^{2}$. \\ Jan Willem van Groenigen ${ }^{2}$
}

Received: 8 August 2017 / Accepted: 22 February 2018 / Published online: 21 March 2018

(C) The Author(s) 2018

\begin{abstract}
Tropical peatlands in the Peruvian Amazon exhibit high densities of Mauritia flexuosa palms, which are often cut instead of being climbed for collecting their fruits. This is an important type of forest degradation in the region that could lead to changes in the structure and composition of the forest, quality and quantity of inputs to the peat, soil properties, and greenhouse gas (GHG) fluxes. We studied peat and litterfall characteristics along a forest degradation gradient that included an intact site, a moderately degraded site, and a heavily degraded site. To understand underlying factors driving GHG emissions, we examined the response of in vitro soil microbial GHG emissions to soil moisture variation, and we tested the potential of pneumatophores to conduct GHGs in situ. The soil phosphorus and carbon content and carbon-to-nitrogen ratio as well as the litterfall nitrogen content and carbon-to-nitrogen ratio were significantly affected by forest degradation. Soils from the degraded sites consistently produced more carbon dioxide $\left(\mathrm{CO}_{2}\right)$ than soils from the intact site during in vitro incubations. The response of $\mathrm{CO}_{2}$ production to changes in water-filled pore space (WFPS) followed a cubic polynomial relationship with maxima at 60-70\% at the three sites. Methane $\left(\mathrm{CH}_{4}\right)$ was produced in limited amounts and exclusively under watersaturated conditions. There was no significant response of nitrous oxide $\left(\mathrm{N}_{2} \mathrm{O}\right)$ emissions to WFPS variation. Lastly, the density of pneumatophore decreased drastically as the result of forest degradation and was positively correlated to in situ $\mathrm{CH}_{4}$ emissions. We conclude that
\end{abstract}

Jeffrey van Lent

j.lent@cgiar.org

1 Center for International Forestry Research, Bogor, Indonesia

2 Department for Soil Quality, Wageningen UR, Wageningen, The Netherlands

3 CIFOR, c/o Centro Internacional de la Papa (CIP), Av. La Molina 1895, La Molina, Apdo postal 1558, 15024 Lima, Peru

4 CIAT, Cali, Colombia 
recurrent $M$. flexuosa harvesting could result in a significant increase of in situ $\mathrm{CO}_{2}$ fluxes and a simultaneous decrease in $\mathrm{CH}_{4}$ emissions via pneumatophores. These changes might alter long-term carbon and GHG balances of the peat, and the role of these ecosystems for climate change mitigation, which stresses the need for their protection.

Keywords $\mathrm{CH}_{4} \cdot \mathrm{CO}_{2} \cdot \mathrm{GHG} \cdot$ Mauritia flexuosa $\cdot \mathrm{N}_{2} \mathrm{O} \cdot$ Peat swamp forest $\cdot$ Pneumatophores . Tropical peatland $\cdot$ Water-filled pore space

\section{Introduction}

Tropical peatlands are a globally important carbon stock of 87-350 GtC (Gumbricht et al. 2017; Page et al. 2011) and are crucial for mitigating climate change (Murdiyarso et al. 2013). In addition, tropical peatlands are among the most efficient terrestrial ecosystems for carbon sequestration (Dommain et al. 2011; Page et al. 2004), as continuous input of organic material from lowland tropical evergreen vegetation combined with anaerobic soil conditions lead to a build-up of soil organic matter (SOM) over time (Jauhiainen et al. 2012). In natural conditions, the portion of SOM that is decomposed and emitted as carbon dioxide $\left(\mathrm{CO}_{2}\right)$ or methane $\left(\mathrm{CH}_{4}\right)$ is usually outweighed by the continuous input of fresh litter and roots (Jauhiainen et al. 2005; Hergoualc'h and Verchot 2011; Hoyos-Santillan et al. 2015). Models such as the Holocene Peat Model-HPM (Frolking et al. 2010; Kurnianto et al. 2015) use this balance to predict long-term peat accumulation via vegetation-specific characteristics such as decomposition speed and primary production.

Peru is estimated to harbor one of the largest extents of tropical peatlands in the world (Gumbricht et al. 2017; Draper et al. 2014; Page et al. 2011). Mauritia flexuosa-dominated palm swamp forests are the dominant peatland ecosystem type in the Peruvian Amazon (Draper et al. 2014). Interest in the carbon pools of the Peruvian Amazon peatlands has increased in recent years. Since Lähteenoja et al. (2009a) explored their extent, research further expanded into other fields such as palaeoecology (Roucoux et al. 2013), C stocks estimates (Draper et al. 2014), M. flexuosa management (Virapongse et al. 2017), the characterization of degradation (Hergoualc'h et al. 2017), and greenhouse gas (GHG) fluxes (Teh et al. 2017). The challenges that Peruvian peatlands face are substantially different from those in Southeast Asia. Therein Southeast Asia, peatlands are under great pressure from agricultural expansion, artificial drainage, and fires, which result in considerable GHG emissions (Gaveau et al. 2014; Hergoualc'h and Verchot 2014). In contrast, anthropogenic degradation of peatland in the Peruvian Amazon is mostly related to recurrent harvesting of $M$. flexuosa palms from natural stands without drainage or fire. The fruits from M. flexuosa palms (locally referred to as "Aguaje") and palm weevils (Rhynchophorus palmarum) that grow inside dead palms are highly demanded products in the regional market and are important sources of vitamins and proteins for rural communities (Pacheco Santos 2005). Even though more sustainable (climbing) techniques exist (Horn et al. 2012), fruit harvesting continues to involve cutting down entire palms. The effect of this practice substantially alters the composition and structure of the forest (Hergoualc'h et al. 2017); however, its impact on long-term peat accumulation remains unstudied.

Information about driving factors of GHG fluxes is crucial to accurately model and predict long-term changes in the soil carbon pool and exchanges of GHG with the atmosphere (Ryan and Law 2005). Hereafter and throughout the text, soil $\mathrm{CO}_{2}, \mathrm{CH}_{4}$, and nitrous oxide $\left(\mathrm{N}_{2} \mathrm{O}\right)$ 
fluxes are collectively referred to as GHG fluxes. Factors that drive GHG flux dynamics include, among others, soil substrate quality, nutrient availability, and aeration. Soil waterfilled pore space (WFPS) is commonly used as an indicator for soil aeration. For a wide range of soils, the WFPS has been reported to affect the emissions of $\mathrm{CO}_{2}$ (e.g., Husen et al. 2014; Howard and Howard 1993), $\mathrm{CH}_{4}$ (e.g., Verchot et al. 2000; Del Grosso et al. 2000), and $\mathrm{N}_{2} \mathrm{O}$ (e.g., van Lent et al. 2015; Davidson et al. 2000). Maximum respiration rates typically occur around 60\% WFPS (Linn and Doran 1984); below this level, the microbial activity is limited by water, and above it, oxygen deficiency hampers microbial respiration (Moyano et al. 2013). $\mathrm{N}_{2} \mathrm{O}$ emissions predominantly arise from nitrification and denitrification (Davidson et al. 2000), and maximum $\mathrm{N}_{2} \mathrm{O}$ emission reported by Van Lent et al. (2015) was around $60 \%$ WFPS for a wide range of tropical mineral soils. Methanogenesis is the anaerobic microbial decomposition of organic material, which occurs in waterlogged soils or in anaerobic microaggregates, whereas methanotrophy takes place in parts of the soil where oxygen is available. Both processes concur in soils, and - among other factors - are modulated by soil structure and WFPS\% (Smith et al. 2003; Teh et al. 2005). In waterlogged soils at $100 \%$ WFPS, methanogenesis is likely the dominant process, whereas at WFPS $<100 \% \mathrm{CH}_{4}$ is solely produced in anoxic microsites and part of the $\mathrm{CH}_{4}$ is oxidized.

GHG production is also influenced by the quality and quantity of fresh roots and litter that enter the soil (Updegraff et al. 1995). For instance, in the DAYCENT model, the carbon-to nitrogen-ratio ( $\mathrm{C} / \mathrm{N}$ ratio) of different plant parts is an input for SOM turnover rates, and consecutively influences $\mathrm{C}$ mineralization, which are in turn controlled by factors such as soil moisture, temperature, and texture (Parton et al. 1993, Del Grosso et al. 2001). In addition, Oktarita et al. (2017) found increased soil $\mathrm{N}_{2} \mathrm{O}$ when soil $\mathrm{C} / \mathrm{N}$ ratios decreased. We hypothesize that palm harvesting leads to changes in vegetation composition, and in turn to alteration of litter inputs by secondary regrowth and the $\mathrm{C} / \mathrm{N}$ ratio of the soil substrate. We expect this change in substrate to result in increased decomposition in areas where palms are harvested as compared to undisturbed conditions, which would be reflected in higher GHG emissions in those disturbed sites.

In saturated conditions, aerating roots potentially play an important role for soil GHG fluxes. Plants need to adapt themselves to cope with anoxic conditions (Bruhn et al. 2012). Such adaptations are generally aimed at increasing the influx of oxygen to the root zone through adventitious roots, lenticels, and enlarged aerenchymous tissues (Haase and Rätsch 2010). This acquired oxygen is used for a variety of essential plant functions, such as root respiration (Colmer and Voesenek 2009). A thickened exodermis around the aerenchyma acts like a barrier and only allows for oxygen to leak near and around the root tip (van Noordwijk et al. 1998). Granville (1969) described the presence of such tissues in the aerating pneumatophores of $M$. flexuosa palms. These pneumatophores may also conduct $\mathrm{N}_{2} \mathrm{O}$ or $\mathrm{CH}_{4}$ produced in the anoxic soil layers to the atmosphere, as has been shown for aerenchymous tissues in the stalks of rice (see, e.g., Minoda and Kimura 1994) as well as for tree stem lenticels in temperate and tropical forested wetlands (Gauci et al. 2010; Pangala et al. 2013). In this way, $\mathrm{CH}_{4}$ is directly emitted from the soil, and avoids potential oxidation in upper aerobic soil layers. Similarly, dissolved $\mathrm{N}_{2} \mathrm{O}$ and $\mathrm{CH}_{4}$ can be taken up by roots and subsequently emitted during root or leaf respiration (Pihlatie et al. 2005; Gauci et al. 2010). The existence and the contribution of pneumatophores to total soil GHG emissions have not been reported for palm swamp forests in the Amazon.

Current practices of palm harvesting in the Peruvian Amazon may lead to changes in soil moisture, alteration of the quality of substrate inputs, and decreases in aerating 
pneumatophores. However, to date, there is no assessment on how these changes could affect GHG emissions. In this context, we set as a first objective for this study to test the response of GHG production to varying levels of WFPS, across a gradient of forest degradation involving substrate alteration. Secondly, we aimed to evaluate the contribution of aerating pneumatophores to surface GHG fluxes in undisturbed and degraded palm swamp sites.

\section{Method}

We conducted two experiments. The first one was to determine the response of soil microbial GHG emissions to variations in soil moisture and was performed in vitro with samples without live roots. In the second experiment, we estimated the potential of root pneumatophores to conduct GHGs by relating pneumatophore densities to corresponding in situ soil GHG fluxes. The effect of degradation was assessed by including three sites differing in level of degradation. We acknowledge (and further discuss) the limits of our experimental design, which include no field-level replication for each degradation level.

\subsection{Study site}

The study was conducted southwest of the city of Iquitos, in the province of Loreto in the Peruvian Amazon. The area exhibits a tropical humid climate with an average annual precipitation of $3087 \mathrm{~mm}$ and a weak dry season between June and September (Marengo 1998). Mean annual temperature is $27^{\circ} \mathrm{C}$, with average daily minima around $20-22^{\circ} \mathrm{C}$ and maxima around $29-31{ }^{\circ} \mathrm{C}$ (Marengo 1998). Humidity is at $80-90 \%$ year-round.

The palm swamp peatlands were located near Lake Quistococha (S $3^{\circ} 49.75000^{\prime} \mathrm{W} 73^{\circ}$ $\left.19.11333^{\prime}\right)$. Peat deposits up to $5 \mathrm{~m}$ thick have been reported, with the $390-400 \mathrm{~cm}$ layer radiocarbon dated at $2335 \pm 15$ cal. BP (Lähteenoja et al. 2009a). Permanently waterlogged palm swamp originated around 1000 years ago, while the $M$. flexuosa-dominated vegetation cover observed today was established around 600 years ago (Roucoux et al. 2013). The flooding regime plays an important role for the vegetation development during these time scales. There is currently no man-made drainage in the area and the water table rarely goes deeper than $20 \mathrm{~cm}$ below soil surface level (Kelly et al. 2014). The peatlands occasionally flood; Roucoux et al. (2013) mention flooding events in $1998(30 \mathrm{~cm})$ and $2012(100 \mathrm{~cm})$. We observed another 100-cm flooding during the 2015 El Niño (van Lent, unpublished data). The area likely receives nutrients during these flooding events, as well as during the annual Amazon River flood pulses. In the region, both minerotrophic (nutrient rich) and ombrotrophic (nutrient poor) peatlands have been reported (Lähteenoja et al. 2009b). Teh et al. (2017) characterized the Quistococha peatland in transition between minerotrophic and ombrotrophic conditions, while and Lähteenoja et al. (2009b) characterized it as minerotrophic.

The present study is part of a long-term experiment monitoring soil GHG fluxes along the previously mentioned gradient of forest degradation. The experimental design comprised an intact site ("I," S $03^{\circ} 49.949^{\prime} \mathrm{W} 073^{\circ} 18.851^{\prime}$ ), a moderately degraded site (“mD," S $03^{\circ}$ $50.364^{\prime} \mathrm{W} 073^{\circ} 19.501^{\prime}$ ), and a heavily degraded site (“hD," S $03^{\circ} 48.539^{\prime} \mathrm{W} 073^{\circ} 18.428^{\prime}$ ). The sites are part of the same peatland complex and are 1.3-1.7 km distant to the Itaya River, one of the anastomosing channels of the Amazon river (Fig. 1).

The I site was located within the Quistococha regional reserve (369 ha), an officially protected area since it was registered as a national touristic park in 1984 (Resolución Suprema No 223-84 


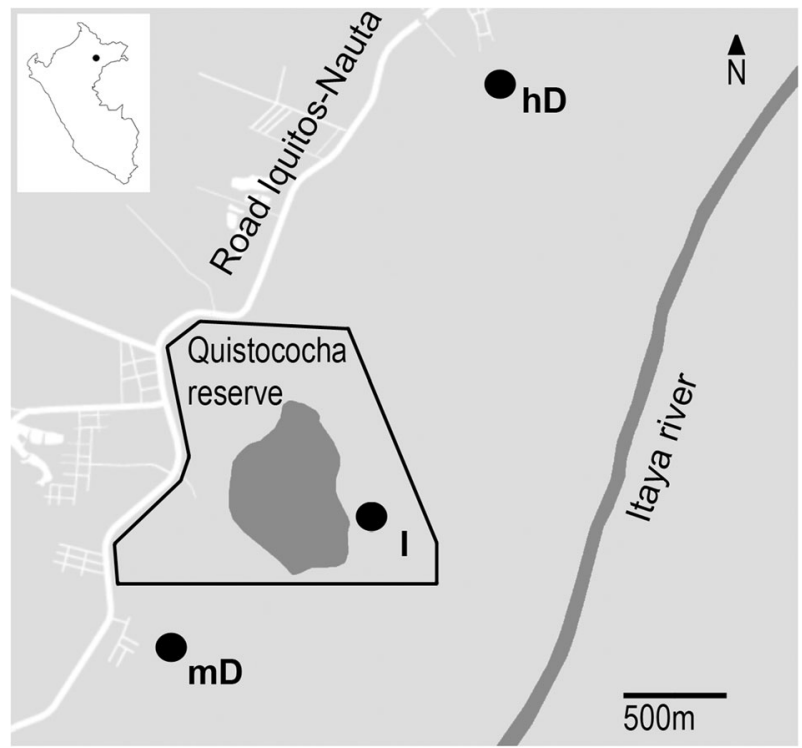

Fig. 1 Map of the study location near Iquitos, Peru. The locations along the Itaya River of the intact (I), moderately $(\mathrm{mD})$, and highly (hd) degraded sites are indicated with black dots. Both degraded sites are close to settlements (white lines represent streets). The black line around the Quistococha lake (dark gray) delimits the border of the reserve

ITI/tur). The other two sites were adjacent to the reserve and are utilized by local villagers for extraction of M. flexuosa fruits, collection of palm weevils (R. palmarum), and timber harvesting. The common, unsustainable practice is to cut down entire palms for fruit and weevil collection (Horn et al. 2012). Recurrent harvesting has resulted in a reduced canopy closure at the $\mathrm{mD}$ site, which is close to a village founded in 2011 . The $\mathrm{hD}$ site is close to a village that expanded in 2014 , according to satellite images, and has few standing palm trees left.

\subsection{Soil and litterfall properties}

Peat depth was measured with a soil probe at six locations per site (Bhomia et al. unpublished). Eighteen samples per site were collected from the top $5 \mathrm{~cm}$ using a metal ring (radius = $4.5 \mathrm{~cm}$ ). Samples were dried until constant weight at $60{ }^{\circ} \mathrm{C}$ and bulk density was determined from the dry mass per volume of the ring. Six samples per site (three from hollows and three from hummocks) were ground, homogenized, and sent for determination of total carbon (C) and nitrogen $(\mathrm{N})$ by the induction furnace method (Costech EA C-N Analyzer); Calcium (Ca), Potassium (K), Magnesium (Mg), Sodium (Na) by the ammonium acetate method (Ross and Ketterings 2011); and Copper (Cu), Manganese (Mn), Zinc (Zn), and Phosphorus (P) by the Mehlich 3 method (Ziadi and Tran 2007). All analyses were conducted by the University of Hawaii-Hilo. The $\mathrm{Ca}$ and $\mathrm{Mg}$ content is useful for determining the nutrient status of the sites. A $\mathrm{Ca} / \mathrm{Mg}$ ratio $<6$ classifies as a nutrient poor, rain-fed ombrotrophic peatland; while a ratio $>6$ is indicative of inputs from river water and classifies as a minerotrophic peatland (Lähteenoja et al. 2009b).

Vegetation litter was collected from 27 litter traps (total surface $=4.32 \mathrm{~m}^{2}$ ) per site in September 2016. Although flowering and fruiting can be seasonal, litterfall rates are dominated 
by leaf litter and samples were representative for our sites. Aguila-Pasquel et al. (2014) reports litterfall rates near our study location and showed that leaf litter $\mathrm{C}$ represents $\sim 70 \% \pm 2 \%$ throughout the year, and $77 \%$ in September alone. The litter was weighed and a $\sim 100 \mathrm{~g}$ subsample was dried in an oven at $40{ }^{\circ} \mathrm{C}$ until constant weight. Litterfall $\mathrm{C}$ and $\mathrm{N}$ concentration was analyzed as described above.

\subsection{In vitro incubation}

The objective of this experiment was to evaluate the effect of WFPS on GHG flux rates along the gradient of forest degradation. For this purpose, two $500 \mathrm{~g}$ soil samples were excavated from the top $30 \mathrm{~cm}$ in three plots at $\sim 150 \mathrm{~m}$ distance from each other within each site. Large roots were manually removed on-site and the remaining soil was air-dried at approximately $25-30{ }^{\circ} \mathrm{C}$ for 3 to 5 days. Next, smaller roots and aggregates were removed by gently crushing and sieving the soil (mesh size $2 \mathrm{~mm}$ ). Then the six samples were mixed to obtain one homogenous sample per site and stored at $7{ }^{\circ} \mathrm{C}$ for a week until the start of the incubation.

A pilot incubation experiment was carried out to determine the appropriate incubation time and quantity of air-dried soil needed. The first objective of the pilot was to obtain a linear increase in $\mathrm{CO}_{2}$ concentrations over time, while not exceeding the maximum $\mathrm{CO}_{2}$ standard gas concentration used to calibrate the gas chromatograph ( $4990 \mathrm{ppm} \mathrm{CO}_{2}$ ). The second objective was to evaluate the amount of water needed to bring the samples to WFPS values ranging from 20 to $100 \%$.

In the final incubation experiment, triplicates of $15 \mathrm{~g}$ air-dried soil were placed in an Erlenmeyer flask $(600 \mathrm{ml})$ and treated with $0,10,20,30,40,50$, and $70 \mathrm{ml}$ of DI water. The $70-\mathrm{ml}$ treatment intentionally surpassed the water holding capacity to mimic flooded field conditions. Soil and water were mixed with a mechanical shaker and left uncapped to settle for $48 \mathrm{~h}$, to allow the microbial community to stabilize following the drying and rewetting process. Afterwards, GHG flux measurements were performed on four consecutive days. At each day, the flasks were closed and four air samples were taken from the headspace at 1-h intervals. At the onset, flasks were vented with ambient air for $10 \mathrm{~s}$ using a vacuum pump and then closed with a rubber stopper equipped with a sampling port. After closure, air samples $(10 \mathrm{ml})$ were taken with a disposable syringe and stored in $10 \mathrm{ml}$ evacuated glass vials with septa caps until further analysis by gas chromatography. Laboratory air temperature and pressure were recorded after the first headspace sample was taken.

Between sampling dates, the flasks were left uncapped at room temperature $\left(\sim 21^{\circ} \mathrm{C}\right)$ and the wet soil slurry weight was kept constant through addition D.I. water. At the end of the experiment, samples were oven-dried at $60{ }^{\circ} \mathrm{C}$ until constant weight, followed by samplespecific bulk density determination. The WFPS was calculated following the formula by Linn and Doran (1984), assuming a particle density of $1.4 \mathrm{~g} \mathrm{~cm}^{-3}$ (Driessen and Rochimah 1976).

GHG fluxes from individual flasks at each sampling day were calculated by linear regression of GHG concentration against time, expressed per mass of oven-dried soil. C mineralization was calculated as the site-averaged $\mathrm{CO}_{2}$ production rate per unit $\mathrm{C}$ in the soil. WFPS values were calculated for each water addition treatment $(n=12)$ to test the response of GHG fluxes to WFPS per site.

\subsection{Pneumatophore gaseous exchanges experiment}

The objective of this experiment was to determine the potential of root pneumatophores to conduct $\mathrm{CO}_{2}, \mathrm{CH}_{4}$, or $\mathrm{N}_{2} \mathrm{O}$ from the soil to the atmosphere. As part of a long-term GHG 
monitoring study, nine chambers per site were installed in July 2014 (I), September 2014 (hD), and April $2015(\mathrm{hD})$ at $>1.5 \mathrm{~m}$ distance from a tree or a palm in order to avoid the elevated areas surrounding trunks (hummocks). The lower parts (hollows) are more often flooded, and highest density of pneumatophores is observed in hollows (Granville 1969). These areas represent $>80 \%$ of the total surface area in all three sites (data not shown). $\mathrm{CO}_{2}, \mathrm{CH}_{4}$, and $\mathrm{N}_{2} \mathrm{O}$ fluxes were measured using the static closed chamber method, and measured monthly between August and October 2015. The chambers (25 $\mathrm{cm}$ height and $30 \mathrm{~cm}$ diameter) were pushed $3-5 \mathrm{~cm}$ in the soil. Their lids were equipped with a center port for gas sampling and a vent to equalize pressure inside the chamber with that outside. At the start of each measurement, chambers were vented, closed, and gas samples $(30 \mathrm{ml})$ were taken from the enclosed headspace at $t=0,10,20$, and $30 \mathrm{~min}$ using a 50-ml disposable syringe. Twenty milliliters of this sample were injected in pre-evacuated glass vials $(10 \mathrm{ml})$ to store the samples under overpressurized conditions. The vials were sealed with silicon to prevent leakage during transportation by air from Iquitos to Lima. Air pressure and air and soil temperatures were monitored concomitantly with gas flux measurements. Soil temperature was measured with a probe outside, but within $20 \mathrm{~cm}$ of the chamber to prevent soil disturbance.

The number of pneumatophores within each permanent chamber was counted in September 2015. The water table depth (WTD) and WFPS were measured simultaneously with GHG sampling. The WTD was obtained from PVC wells $(10 \mathrm{~cm}$ diameter, $1.5 \mathrm{~m}$ height) installed within $50 \mathrm{~cm}$ of each GHG flux chamber. The WFPS was calculated from soil samples collected from the top $10 \mathrm{~cm}$ soil layer at each GHG flux chamber, using the same method as described for the in vitro incubation.

\subsection{Gas analysis and flux calculation}

Gas samples were analyzed at the CIFOR laboratory in Lima, Peru using a gas chromatograph (GC, Perkin Elmer, USA) within 1 week of sample collection on average. The GC was equipped with a ${ }^{63} \mathrm{Ni}$ electronic capture detector (ECD) for $\mathrm{N}_{2} \mathrm{O}$ analysis and with a flame ionization detector (FID) with a methanizer for analysis of $\mathrm{CH}_{4}$ and $\mathrm{CO}_{2}$. The flux was computed by linear regression against time using the four sampling points. Samples were discarded following a visual quality check for leakage or departure from linearity. Leakage corresponded to a sample for which the concentration of the three GHGs was similar to atmospheric concentrations (except for the sample taken immediately after closure). Departure from linearity of the regression happens because the chamber creates an artifact by reducing the concentration gradient between the soil and the atmosphere (Collier et al. 2014). This usually happens for the last sample time-point.

\subsection{Statistical analysis}

Statistical analysis was performed using the software IBM SPSS Statistics for Windows 21.0 (IBM Corp. 2012) and statistical significance was set at an alpha level of 5\%. Normality was tested using the Shapiro-Wilk test, and visual interpretation of Q-Q plots. Comparisons between sampling dates and replicates were done with ANOVA's and post-hoc Bonferroni tests for $\mathrm{CO}_{2}$ in case of significant differences between groups. The in vitro $\mathrm{CH}_{4}, \mathrm{~N}_{2} \mathrm{O}$, and the soil nutrients were compared with the Kruskal-Wallis test and pairwise comparisons. The comparisons between sites should be used with care due to the low sample size. Regression models were constructed with the average WFPS and GHG flux per water addition treatment. 
The response of the fluxes to WFPS was modeled using cubic and quadratic polynomial functions that allow for a decrease in fluxes at high WFPS $\%$. The $r^{2}$ values were used to estimate which model fit best the observations. The cumulative in situ $\mathrm{CH}_{4}$ fluxes and pneumatophore densities were positively skewed and therefore log-transformed to improve normality. Pneumatophore density was correlated with cumulative $\mathrm{CH}_{4}$ fluxes.

\section{Results}

\subsection{Soil and litterfall properties}

Soil and litterfall properties are presented in Table 1 . The peat at the $\mathrm{hD}$ site was shallower than at the other sites. Bulk densities overall were low which is typical of peat soils. The $\mathrm{Ca} / \mathrm{Mg}$ ratios were similar among sites and were $>6$, indicating minerotrophic conditions. Soil $\mathrm{P}, \mathrm{C}$, and $\mathrm{C} / \mathrm{N}$ ratio at the $\mathrm{hD}$ site exhibited lower values than the values at the other sites. Litterfall $\mathrm{N}$ and $\mathrm{C} / \mathrm{N}$, respectively, increased and decreased with increasing level of degradation. Differences between hummocks and hollows were non-significant, except for $\mathrm{Mn}$, which showed higher concentrations in hummocks.

\subsection{Response of in vitro GHG fluxes from root-free soils to WFPS variation}

Average $\mathrm{CO}_{2}$ production across WFPS treatments was consistently lower $(p=0.01)$ in soils from the I site $\left(1.67 \pm 0.18 \mu \mathrm{g} \mathrm{C}-\mathrm{CO}_{2} \mathrm{~g}^{-1} \mathrm{~d}\right.$.w. $\left.\mathrm{h}^{-1}\right)$, compared to production in soils from the $\mathrm{mD}(2.34 \pm 0.16)$ and $\mathrm{hD}$ sites $(2.45 \pm 0.16)$ (Table 2$)$. The difference between sites was more pronounced when expressed as $\mathrm{C}$ mineralization: $3.9 \pm 0.4,5.1 \pm 0.4$, and $7.0 \pm 0.5 \mu \mathrm{g} \mathrm{C} \mathrm{g}^{-1} \mathrm{C}$ $\mathrm{h}^{-1}$ for the I, $\mathrm{mD}$, and $\mathrm{hD}$ sites, respectively. At all sites, the best model fitting the response of $\mathrm{CO}_{2}$ to WFPS was cubic polynomial with maxima between 60 and $70 \%$ WFPS (Fig. 2). The difference in $\mathrm{CO}_{2}$ production between sites was largest at the maximum flux, where soils from the $\mathrm{mD}$ and $\mathrm{hD}$ site produced 134 and $139 \%$ of that produced by soils from the I site, respectively. Soil $\mathrm{CO}_{2}$ production remained relatively stable during the incubation period. There were only a few cases where fluxes varied between sampling dates (Appendix).

Fluxes of $\mathrm{CH}_{4}$ from the $\mathrm{hD}$ site were significantly higher compared to fluxes from the I and $\mathrm{mD}$ sites, at all WFPS levels ( $p<0.01$; Table 2). Soils from the I and $\mathrm{mD}$ sites were $\mathrm{CH}_{4}$ sinks for all water addition treatments. The soil from the $\mathrm{hD}$ site was a net $\mathrm{CH}_{4}$ sink below $70 \%$ WFPS $\left(-0.15 \pm 0.09 \mathrm{ng} \mathrm{C}-\mathrm{CH}_{4} \mathrm{~g}^{-1}\right.$ d.w. $\left.\mathrm{h}^{-1}\right)$, thereafter switching to a net source $(6.5 \pm 0.6 \mathrm{ng}$ $\mathrm{C}-\mathrm{CH}_{4} \mathrm{~g}^{-1}$ d.w. $\mathrm{h}^{-1}$ ). The response of $\mathrm{CH}_{4}$ fluxes to varying WFPS was best described by a quadratic function. For the I and $\mathrm{mD}$ sites, the response was very weak, whereas for the $\mathrm{hD}$ site $\mathrm{CH}_{4}$ fluxes showed a strong increase above 54\% WFPS. Soils from the I and $\mathrm{mD}$ sites did not display significant differences in flux rate over time, whereas soil $\mathrm{CH}_{4}$ production from the $\mathrm{hD}$ site increased over time $\left(r^{2}=0.14, p<0.01\right)$ (Appendix).

Averaged $\mathrm{N}_{2} \mathrm{O}$ fluxes from the I site $\left(36.68 \pm 7.86 \mathrm{ng} \mathrm{N}-\mathrm{N}_{2} \mathrm{O} \mathrm{g}^{-1}\right.$ d.w. $\left.\mathrm{h}^{-1}\right)$ were significantly higher than fluxes from the $\mathrm{mD}(2.80 \pm 0.65)$ and $\mathrm{hD}$ sites $(0.08 \pm 0.06)$ for WFPS $>70 \%$ $(p<0.01)$, but not for WFPS $<70 \%(p=0.6)$. $\mathrm{N}_{2} \mathrm{O}$ production in soils from the I site steeply increased above $70 \%$ WFPS and decreased in the flooded treatment. $\mathrm{N}_{2} \mathrm{O}$ production in soils from the $\mathrm{mD}$ and $\mathrm{hD}$ site did not respond significantly to variation in WFPS. Production rates reduced over time for the $>67 \%$ WFPS treatments of the $\mathrm{I}(p<0.01)$ and $\mathrm{mD}$ sites $(p<0.01)$; soils displayed overall larger fluxes on the first day of incubation compared to other days. 


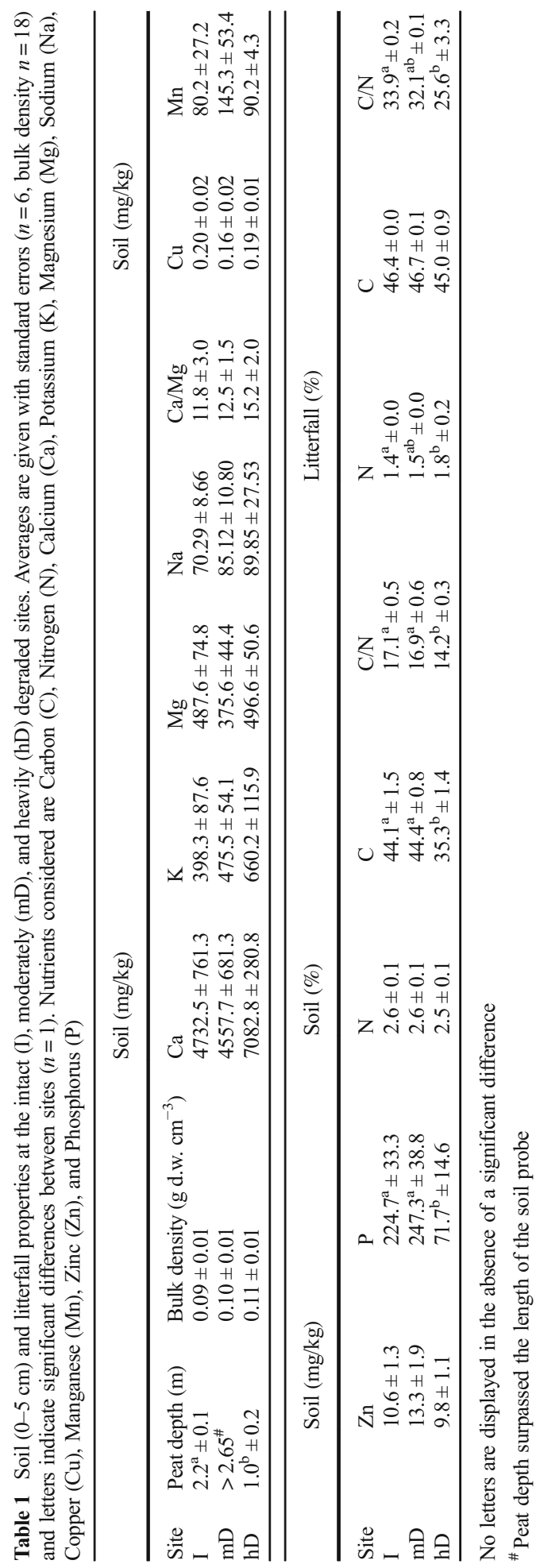




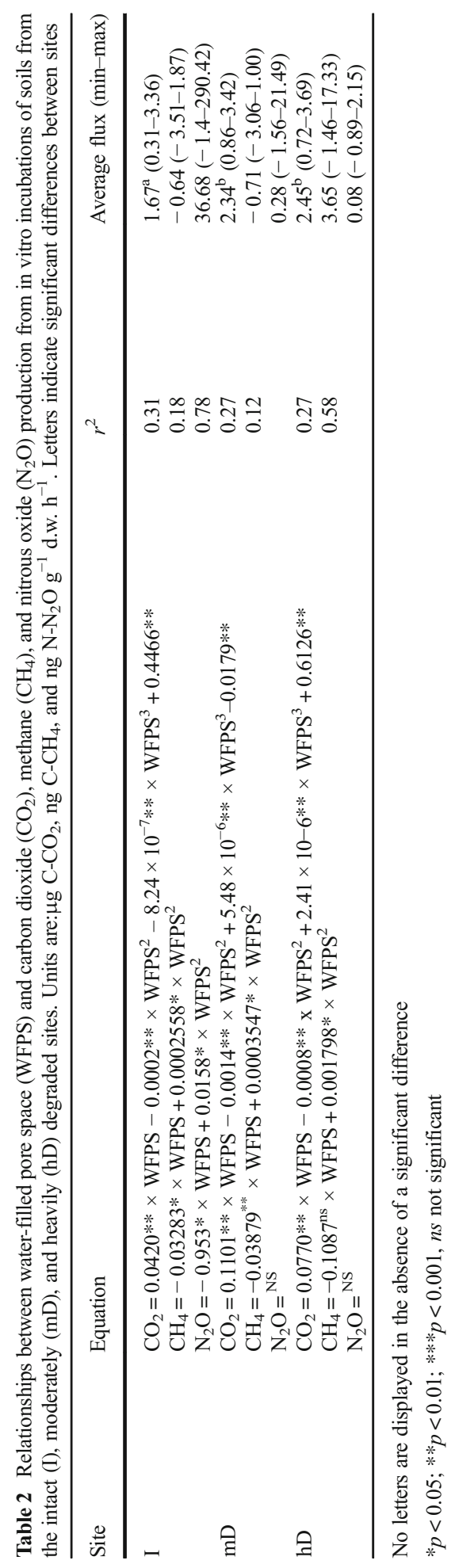


Fig. 2 In vitro response of soil carbon dioxide $\left(\mathrm{CO}_{2}\right)(\mathbf{a})$, methane $\left(\mathrm{CH}_{4}\right)(\mathbf{b})$, and nitrous oxide $\left(\mathrm{N}_{2} \mathrm{O}\right)$ (c) fluxes to varying water-filled pore space (WFPS). Curves indicate statistical models for the intact (I), moderately $(\mathrm{mD})$, and heavily (hD) degraded sites. Soils incubated under flooded conditions are indicated by shaded areas. Error bars present the standard error $(n=$ 12)
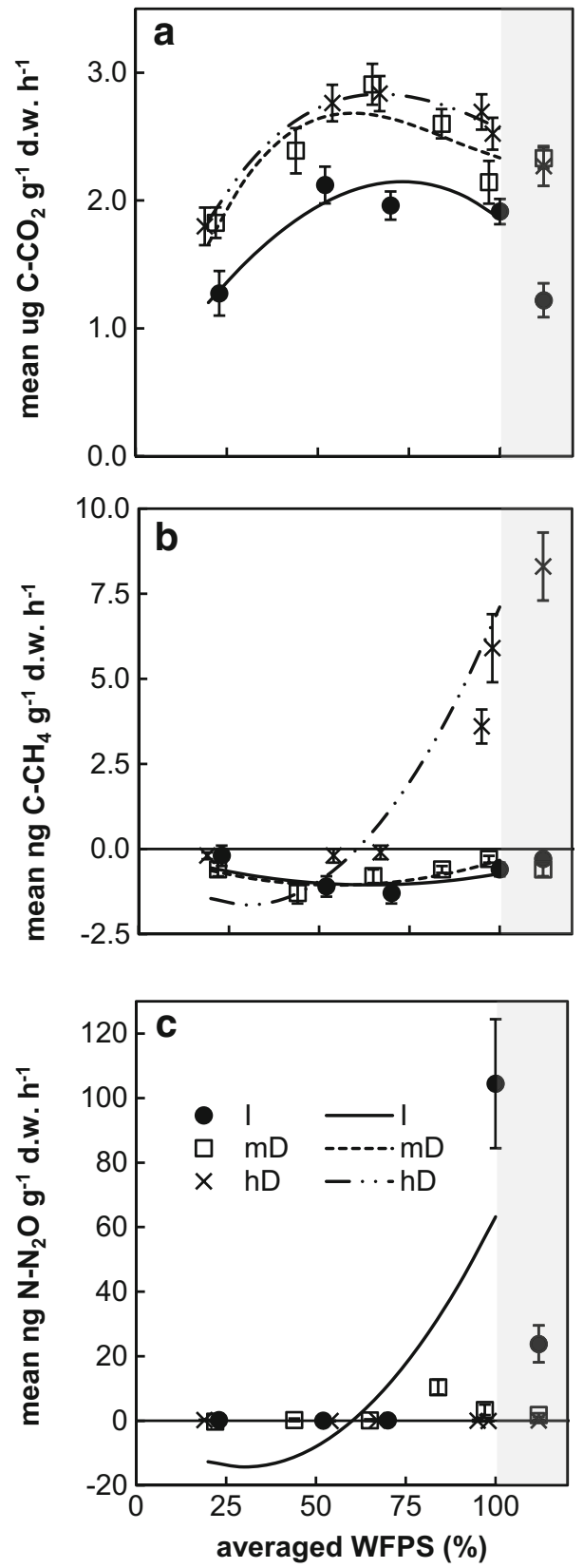

\subsection{Contribution of aerating roots to in situ GHG fluxes}

Pneumatophore density was higher at the I site $\left(5.6 \pm 1.2\right.$ pneumatophores $\left.\mathrm{dm}^{-2}\right)$ compared to density at the $\mathrm{mD}(1.9 \pm 0.6)$ and $\mathrm{hD}(0.3 \pm 0.2)$ sites $(p<0.01)$. At the I site, all chambers had at least 0.7 pneumatophore $\mathrm{dm}^{-2}$, whereas at the $\mathrm{mD}$ and $\mathrm{hD}$ sites 22 and $67 \%$ of the 
chambers, respectively, did not have pneumatophores at all. $\mathrm{CH}_{4}$ fluxes varied strongly within sites, and cumulative $\mathrm{CH}_{4}$ fluxes were not significantly different between sites $(p=0.45)$. Among all GHG, only $\mathrm{CH}_{4}$ fluxes were significantly correlated to pneumatophore density (Fig. 3). The relationship was most robust for the I site $\left(r^{2}=0.5, p=0.03\right)$. Regression lines for pneumatophore densities and $\mathrm{CO}_{2}$ or $\mathrm{N}_{2} \mathrm{O}$ were insignificant and had nearly horizontal slopes. Water table depth (WTD) varied significantly between sites, in the order $\mathrm{I}<\mathrm{hD}<\mathrm{mD}$ with respective averages of $-21.9 \pm 1.6,-6.5 \pm 1.4$, and $-2.0 \pm 1.2 \mathrm{~cm}$ below the soil surface, respectively. Average WFPS followed the same trend as the WTD, with $\mathrm{I}=\mathrm{hD}<\mathrm{mD}$, and averages of $60 \pm 2,69 \pm 4$, and $94 \pm 2 \%$, respectively.

\section{Discussion}

The topsoil at all three sites displayed minerotrophic properties, in agreement with findings by Lähteenoja et al. (2009a) at the Quistococha reserve. The sites exhibited similar levels of cations and a similar minerotrophic state. Accordingly, the lower soil $\mathrm{C}$ content and $\mathrm{C} / \mathrm{N}$ ratio at the $\mathrm{hD}$ site compared to those at the other sites may indicate a higher degree of humification (Tfaily et al. 2014). The lower P content at the $\mathrm{hD}$ site than at the other sites may also suggest a more advanced decomposition status of the peat (Jordan et al. 2007; Könönen et al. 2015). Recurrent harvesting of M. flexuosa palms leads to shifts in forest structure and composition (Hergoualc'h et al. 2017). Bhomia et al. (unpublished) found that the I site harbored a higher density of dicot trees $\left(\sim 1500 \mathrm{ha}^{-1}\right)$ than the degraded sites $(\sim$ $\left.700 \mathrm{ha}^{-1}\right)$. Furthermore, the density of palms overall and of $M$. flexuosa palms in particular was much lower at the $\mathrm{hD}$ site (53 and $16 \mathrm{ha}^{-1}$, respectively) than at the I and $\mathrm{mD}$ sites ( 300 and $170 \mathrm{ha}^{-1}$, respectively). The presence of a high number of individuals of Cecropia

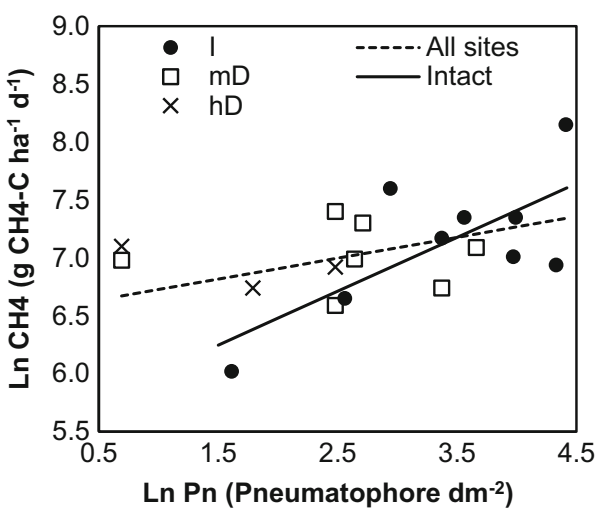

Fig. 3 Relationship between pneumatophore density $(\mathrm{Pn})$ and methane $\left(\mathrm{CH}_{4}\right)$ fluxes in the intact (I), moderately degraded $(\mathrm{mD})$, and heavily degraded $(\mathrm{hD})$ sites. Greenhouse gas chambers with no pneumatophores were excluded $\left(n=9,7\right.$, and 3, respectively). Equations for the regression lines are: $\ln \left(\mathrm{CH}_{4}\right)_{\mathrm{all}}$ sites $=0.2 * \pm 0.1 \times$ $\ln (\mathrm{Pn})+6.5^{* *} \pm 0.3\left(r^{2}=0.2\right)$ and $\ln \left(\mathrm{CH}_{4}\right)_{\text {intact }}=0.5^{*} \pm 0.2 \times \ln (\mathrm{Pn})+5.5^{* *} \pm 0.6\left(r^{2}=0.5\right), *=p<0.05, * *$ $p<0.01$ 
spp.-a pioneer species observed at the $\mathrm{hD}$ site - is indicative of its degraded status. In addition, the gaps formed upon harvesting are colonized by small $(<2 \mathrm{~m})$ fast-growing herbaceous vegetation (personal observation). Such drastic differences in forest structure can be expected to lead to lower above and belowground litter inputs at the degraded sites as compared to inputs at the I site. Differences in forest composition may also induce significant changes in litter quality, as indicated by the difference in litterfall $\mathrm{C} / \mathrm{N}$ ratio between sites (Table 1). Decreased $\mathrm{C} / \mathrm{N}$ ratio of litterfall with increased degradation is in agreement with observations by Feldpausch et al. (2004) along a sequence of secondary forest regeneration in Central Amazonia. During early forest succession the biomass accumulates rapidly and consists mainly of easily decomposable litter and less of wood (Gehring et al. 2005; Guariguata and Ostertag 2001). More readily decomposable litter may on the long-term lead to reduced peat accumulation at the degraded sites (Frolking et al. 2001).

The changes in litter quality and the less-decomposed SOM pool as outlined above could explain the differences in $\mathrm{C}$ mineralization we found between sites. This is in line with Nilsson and Bohlin (1993), who found that more decomposed peat soils produced more $\mathrm{CO}_{2}$ than less decomposed, more fibrous peat soils in temperate climate. In contrast, incubation studies by Jauhiainen et al. (2016) and Swails et al. (2017) showed that soils from degraded peatlands with secondary regrowth or cultivated with oil palm produced less $\mathrm{CO}_{2}$ than soils from intact peat swamp forests. However, the degraded peatlands of Indonesia were drained and burnt, while sites in our study were not. The effect of such drainage and fire practices generally accelerates the peat mineralization (Hergoualc' $h$ and Verchot 2011, 2014). An intact hydrology at our study area might prohibit the easilydecomposable litter in the degraded sites to decompose. During relative dry periods (60$70 \%$ WFPS), the in situ $\mathrm{CO}_{2}$ fluxes in degraded peat swamp forests could show a stronger response to lower WFPS as compared to undisturbed peat swamp forests. Periods with less precipitation are therefore expected to result in increased $\mathrm{CO}_{2}$ fluxes in situ.

The response of $\mathrm{CO}_{2}$ production to changes in WFPS followed a cubic polynomial relationship, which is in agreement with results reported by Howard and Howard (1993) for a wide range of soils and by Husen et al. (2014) for peat soils under oil palm cultivation in Indonesia. The maximum $\mathrm{CO}_{2}$ production at 60-70\% WFPS for all three sites is in accordance with common values around 60\% WFPS found in the literature (Davidson et al. 1998; Linn and Doran 1984), but slightly higher than the $50 \%$ value reported by Husen et al. (2014).

In the incubation study, $\mathrm{CH}_{4}$ was solely produced in soil from the heavily degraded site at anoxic conditions (WFPS $>100 \%$ ), as has been reported by Smith et al. (2003) and similar to $88 \%$ WFPS reported by Melling et al. (2005) for tropical peat swamp forest. The soil samples from the $\mathrm{I}$ and $\mathrm{mD}$ sites were likely not lacking in $\mathrm{C}$ substrate for the methanogens (Table 1), and the water addition treatment mimicking flooded conditions should have ensured anaerobic soil samples. Possibly, $\mathrm{CH}_{4}$ production was inhibited due to high nitrate and other denitrification products, which inhibits methanogenesis in rice paddy soils (Kluber and Conrad 1998a, b). The absence of $\mathrm{N}_{2} \mathrm{O}$ production in the $\mathrm{hD}$ site could indicate a lack of nitrate or other denitrification product in these soils. In addition, the soils from the I and $\mathrm{mD}$ produced large amounts of $\mathrm{N}_{2} \mathrm{O}$ at WFPS $\%>70 \%$, which 
could indicate the inhibition of methanogenesis due to the presence of nitrate or other denitrification products. Most likely, the time for recovery to conditions favoring methanogenesis in the soil samples was inadequate. We did see an effect of increased $\mathrm{CH}_{4}$ production toward the end of the incubation experiment (Appendix), which confirms this lag in recovery.

$\mathrm{N}_{2} \mathrm{O}$ was predominantly produced at WFPS greater than $70 \%$ for soils from the I and $\mathrm{mD}$ sites. Mathieu et al. (2006) used ${ }^{15} \mathrm{~N}$ stable isotope tracers to demonstrate that in water-saturated soils denitrification accounted for $85-90 \%$ of emitted $\mathrm{N}_{2} \mathrm{O}$. Therefore, we expect that $\mathrm{N}_{2} \mathrm{O}$ in our peat soils predominantly originated from denitrification instead of nitrification. In addition, we observed a reduced production with increased incubation time that could indicate a depletion of substrate for denitrification, or a further reduction to dinitrogen $\left(\mathrm{N}_{2}\right)$ (Appendix). In contrast to the soils from the I and $\mathrm{mD}$ sites, the soils from the heavily degraded site did not produce any significant amount of $\mathrm{N}_{2} \mathrm{O}$. The large $\mathrm{CH}_{4}$ flux from the same hD soils indicates highly reducing conditions in the soil sample. Possibly denitrification in these soils predominantly resulted in $\mathrm{N}_{2}$, which is the dominant product of denitrification in wet, anaerobic conditions (Davidson et al. 2000), while at the same it is non-toxic for methanogenesis (Roy and Conrad 1999). The maximum $\mathrm{N}_{2} \mathrm{O}$ production rate occurred at 100 and $84 \%$ WFPS for soils from the I and $\mathrm{mD}$ sites (Fig. 2c), respectively, much above the $60 \%$ value presented by Van Lent et al. (2015) for a wide range of tropical mineral soils. This indicates that nitrification is lacking in these peat soils and $\mathrm{N}_{2} \mathrm{O}$ predominantly originates from denitrification instead.

The absolute flux rates from the incubated soils are of limited use; however, as presented above, we were mainly interested in the relative flux rates that are useful for interpretation and modeling of field-based fluxes. Nevertheless, the average peat $\mathrm{CO}_{2}$ and $\mathrm{CH}_{4}$ flux rates measured in vitro were in the same order of magnitude as in situ rates from the literature. A hypothetical $30-\mathrm{cm}$ peat profile with the overall average bulk density of $0.1 \mathrm{~g} \mathrm{~cm}^{-3}$ and the average maximum in vitro production rate of $2.7 \mu \mathrm{g} \mathrm{C}-\mathrm{CO}_{2} \mathrm{~g}^{-1}$ d.w. $\mathrm{h}^{-1}$ (Fig. $2 \mathrm{a}, 60-70 \%$ WFPS) would result in $\mathrm{CO}_{2}$ surface fluxes of $81 \mathrm{mg} \mathrm{C}-\mathrm{CO}_{2} \mathrm{~m}^{-2} \mathrm{~h}^{-1}$. This compares well to the average value of $79 \mathrm{mg} \mathrm{C}-\mathrm{CO}_{2} \mathrm{~m}^{-2} \mathrm{~h}^{-1}$ reported by a review of soil surface $\mathrm{CO}_{2}$ from tropical peat swamp forests in Southeast Asia (Hergoualc'h and Verchot 2011). The 30-cm depth is expected to represent the soil surface flux since deep peat layers contribute little to total GHG efflux (Moore and Dalva 1997; Jauhiainen et al. 2016). The average maximum in vitro $\mathrm{CH}_{4}$ production rate of the water-saturated soils (WFPS $>95 \%$ ) from the hD site was $5.9 \mathrm{ng} \mathrm{C}-\mathrm{CH}_{4} \mathrm{~g}^{-1}$ d.w. $\mathrm{h}^{-1}$ or $0.18 \mathrm{mg} \mathrm{C}-\mathrm{CH}_{4} \mathrm{~m}^{-2} \mathrm{~h}^{-1}$ which is similar to the rate of $0.33 \mathrm{mg} \mathrm{C}-\mathrm{CH}_{4} \mathrm{~m}^{-2} \mathrm{~h}^{-1}$ reported by Hergoualc'h and Verchot (2014), but an order of magnitude lower than the average of $1.50 \mathrm{mg} \mathrm{C}-\mathrm{CH}_{4} \mathrm{~m}^{-2} \mathrm{~h}^{-1}$ reported from similar $M$. flexuosa palm swamp forests (Teh et al. 2017). In contrast to $\mathrm{CO}_{2}$ and $\mathrm{CH}_{4}, \mathrm{~N}_{2} \mathrm{O}$ fluxes measured in vitro were much higher than rates measured in situ. The average maximum $\mathrm{N}_{2} \mathrm{O}$ production rate from in vitro incubated soils from the $\mathrm{I}$ and $\mathrm{mD}$ sites were 105 and $10 \mathrm{ng} \mathrm{N}-\mathrm{N}_{2} \mathrm{O} \mathrm{g}^{-1}$ d.w. $\mathrm{h}^{-1}$ (respectively, 84 and $100 \%$ WFPS), or 3.2 and $0.3 \mathrm{mg} \mathrm{N}-\mathrm{N}_{2} \mathrm{O}$ $\mathrm{m}^{-2} \mathrm{~h}^{-1}$, respectively. For the soils from the intact site, this was an order of magnitude above the average of $0.74 \mathrm{mg} \mathrm{N}-\mathrm{N}_{2} \mathrm{O} \mathrm{m}^{-2} \mathrm{~h}^{-1}$ reported by Van Lent et al. (2015) for tropical peat soils. Differences between fluxes measured in situ and in vitro may originate from soil 
disturbance during sampling or incubation preparation, differences in active peat layers producing or consuming $\mathrm{N}_{2} \mathrm{O}$ and environmental conditions, or lack of a plant sink for mineralized N (Butterbach-Bahl et al. 2013). Lastly, an artifact could have been created due to an up-build of GHGs in the soil and water suspension between sampling days, which then diffused into the headspace after venting at the onset of the measurements. However, we took special care to minimize this effect by leaving the flasks open between sampling days.

Cumulative in situ $\mathrm{CH}_{4}$ emissions were correlated with pneumatophore density (Fig. 3), indicating a potential role for aerating roots to conduct $\mathrm{CH}_{4}$ to the atmosphere in these peat swamp forests. Recently, vegetation-based $\mathrm{CH}_{4}$ fluxes have been synthesized to represent $5-22 \%$ of the total global $\mathrm{CH}_{4}$ budget, of which $58-78 \%$ is conducted by a variety of plant structures and $22-42 \%$ is thought to be produced by plants themselves (Carmichael et al. 2014; Schlesinger and Bernhardt 2013). Pangala et al. (2013) roughly estimated that $\mathrm{CH}_{4}$ emissions from woody tree stems alone represented $62-81 \%$ of the total ecosystem flux in an Indonesian peat swamp forest, while the contribution of pneumatophores was thought to be negligible $(<2 \%)$. The specific contribution of roots to conduct $\mathrm{CH}_{4}$ has been further studied in Indian (Purvaja et al. 2004) and Australian (Kreuzwieser et al. 2003) mangroves; however, to our knowledge, this study is the first to do so for a tropical palm-dominated swamp forest. Our setup was unable to quantify the contribution of these roots to the total ecosystem flux, but it highlights the need for additional research in order to elucidate the role of pneumatophores for $\mathrm{CH}_{4}$ emissions in these ecosystems, and to investigate to what extent this observation holds with different vegetation compositions and soil types throughout the Amazon. Long-term GHG monitoring studies should therefore include aerating roots as potential sources in their experimental design.

The body of knowledge on tropical M. flexuosa-dominated peatlands in the Peruvian Amazon steadily increased in recent years, even though research in this remote region has its practical limitations. This study should be seen as a first exploration of soil moisture and roots as controlling factors for GHG fluxes along a degradation gradient in this region. Despite no site replication, we were able to find enough variation of the underlying drivers of the processes of interest to detect significant relationship. To be able to make inferences about the effects of degradation on biogeochemical cycles and GHG emissions, we would need to undertake a more extensive and replicated experiment. However, this study does show the importance of various site-specific factors that drive the spatial and temporal variations of GHG emissions, and that recurrent harvesting of $M$. flexuosa could alter the GHG balance on the long-term. Sustainable management of the $M$. flexuosa-dominated peat swamp forests is needed and should aim at providing a continuous source of income for many families, while conserving the peat and its role for climate change mitigation at the same time.

Acknowledgements This research was made possible through support to CIFOR by the United States Agency for International Development (Grant number: AID-BFS-G-11-00002) as part of the CGIAR research programs on Forests, Trees and Agroforestry and Climate Change, Agriculture and Food Security (CCAFS). This research was done in collaboration with partners from the Instituto de Investigaciones de la Amazonía Peruana (IIAP), and we would especially like to thank Dr. Dennis del Castillo Torres and his team for their support. We would like to thank Rupesh Bhomia for the peat depth data. Further, we are grateful to Nicole Mitidieri Rivera and Julio Miguel Grandez Rios for their help in the field and Marcella Dionisio for the GC analysis. 


\section{Appendix}

In vitro soil carbon dioxide $\left(\mathrm{CO}_{2}\right)$, methane $\left(\mathrm{CH}_{4}\right)$, and nitrous oxide $\left(\mathrm{N}_{2} \mathrm{O}\right)$ fluxes during 4 days of incubation for the seven water addition treatments $(n=3)$. Soils were collected from an intact $(\mathrm{I})$, moderately $(\mathrm{mD})$, and heavily $(\mathrm{hD})$ degraded site. Significant differences between dates are indicated with, respectively, abc, $\alpha \beta \gamma$, and $\mathrm{ABC}$ for the $\mathrm{I}, \mathrm{mD}$, and $\mathrm{hD}$ sites. No letters are displayed in the absence of a significant difference.

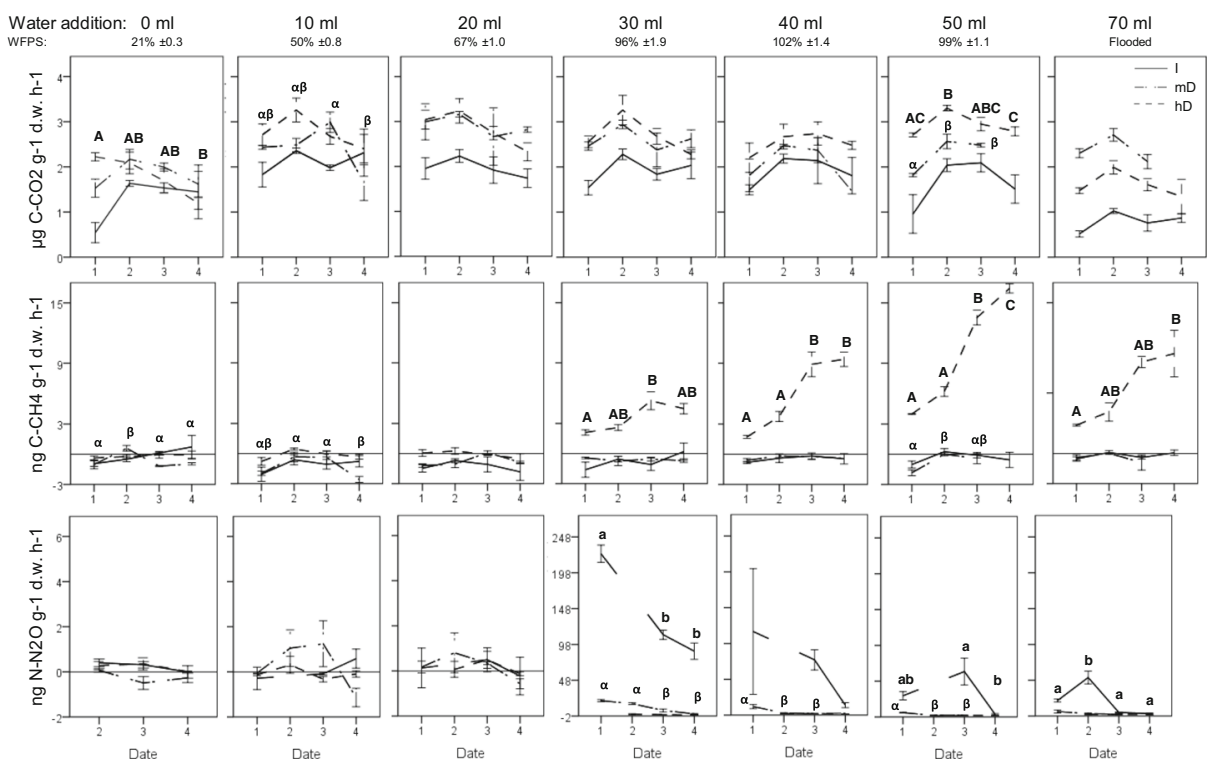

Open Access This article is distributed under the terms of the Creative Commons Attribution 4.0 International License (http://creativecommons.org/licenses/by/4.0/), which permits unrestricted use, distribution, and reproduction in any medium, provided you give appropriate credit to the original author(s) and the source, provide a link to the Creative Commons license, and indicate if changes were made.

\section{References}

Bruhn D, Møller IM, Mikkelsen TN, Ambus P (2012) Terrestrial plant methane production and emission. Physiol Plant 144:201-209. https://doi.org/10.1111/j.1399-3054.2011.01551.x

Butterbach-Bahl K, Baggs EM, Dannenmann M, Kiese R, Zechmeister-Boltenstern S (2013) Nitrous oxide emissions from soils: how well do we understand the processes and their controls? Philos Trans R Soc Lond Ser B Biol Sci 368:20130122. https://doi.org/10.1098/rstb.2013.0122

Colmer TD, Voesenek LACJ (2009) Flooding tolerance: suites of plant traits in variable environments. Funct Plant Biol 36:665. https://doi.org/10.1071/FP09144

Carmichael MJ, Bernhardt ES, Bräuer SL, Smith WK (2014) The role of vegetation in methane flux to the atmosphere: should vegetation be included as a distinct category in the global methane budget? Biogeochemistry 119:1-24. https://doi.org/10.1007/s10533-014-9974-1

Collier SM, Ruark MD, Oates LG, Jokela WE, Dell CJ (2014) Measurement of greenhouse gas flux from agricultural soils using static chambers. J Vis Exp 90:e52110-e52110. https://doi.org/10.3791/52110 
Davidson EA, Belk E, Boone RD (1998) Soil water content and temperature as independent or confounded factors controlling soil respiration in a temperate mixed hardwood forest. Glob Chang Biol 4:217-227. https://doi.org/10.1046/j.1365-2486.1998.00128.x

Davidson EA, Keller M, Erickson HE et al (2000) Testing a conceptual model of soil emissions of nitrous and nitric oxides. Bioscience 50:667. https://doi.org/10.1641/0006-3568(2000)050[0667:TACMOS]2.0.CO;2

de Granville J-J (1969) Aperçu sur la structure des Pneumatophores de 2 espèces des sols hydromorphes: Mauritia flexuosa L. et Euterpe oleracea Mart. (Palmae) - généralisation au système respiratoire racinaire d'autres palmiers. Dissertation, Centre Orstom de Cayenne

del Aguila-Pasquel J, Doughty CE, Metcalfe DB, Silva-Espejo JE, Girardin CAJ, Chung Gutierrez JA, NavarroAguilar GE, Quesada CA, Hidalgo CG, Reyna Huaymacari JM, Halladay K, del Castillo Torres D, Phillips O, Malhi Y (2014) The seasonal cycle of productivity, metabolism and carbon dynamics in a wet aseasonal forest in north-west Amazonia (Iquitos, Peru). Plant Ecol Divers 7:71-83. https://doi.org/10.1080 $/ 17550874.2013 .798365$

Del Grosso SJ, Parton WJ, Mosier A et al (2000) General model for $\mathrm{N}_{2} \mathrm{O}$ and $\mathrm{N}_{2}$ gas emissions from soils due to dentrification. Glob Biogeochem Cycles 14:1045-1060. https://doi.org/10.1029/1999GB001225

Del Grosso SJ, Parton WJ, Mosier A et al (2001) Simulated interaction of carbon dynamics and nitrogen trace gas fluxes using the DAYCENT model. In: Shaffer MJ, Ma L, Hansen S (eds) Modeling carbon and nitrogen dynamics for soil management. Lewis Publishers, Boca Raton, Florida, USA, pp 303-332

Dommain R, Couwenberg J, Joosten H (2011) Development and carbon sequestration of tropical peat domes in south-east Asia: links to post-glacial sea-level changes and Holocene climate variability. Quat Sci Rev 30: 999-1010. https://doi.org/10.1016/j.quascirev.2011.01.018

Draper FC, Roucoux KH, Lawson IT, Mitchard ETA, Honorio Coronado EN, Lähteenoja O, Torres Montenegro L, Valderrama Sandoval E, Zaráte R, Baker TR (2014) The distribution and amount of carbon in the largest peatland complex in Amazonia. Environ Res Lett 9:124017. https://doi.org/10.1088/1748-9326/9/12/124017

Driessen P, Rochimah L (1976) The physical properties of lowland peats from Kalimantan, Indonesia. In: Peat and Podzolic Soils and their Potential for Agriculture in Indonesia (pp 56-73). Soil Research Institute, Bogor, Indonesia

Feldpausch TR, Rondon MA, Fernandes ECM, Riha SJ, Wandelli E (2004) Carbon and nutrient accumulation in secondary forests regenerating on pastures in Central Amazonia. Ecol Appl 14:164-176. https://oi. org/10.1890/01-6015

Frolking S, Roulet NT, Moore TR, Richard PJH, Lavoie M, Muller SD (2001) Modeling northern peatland decomposition and peat accumulation. Ecosystems 4:479-498. https://doi.org/10.1007/s10021-001-0105-1

Frolking S, Roulet NT, Tuittila E, Bubier JL, Quillet A, Talbot J, Richard PJH (2010) A new model of Holocene peatland net primary production, decomposition, water balance, and peat accumulation. Earth Syst Dyn 1:121. https://doi.org/10.5194/esd-1-1-2010

Gauci V, Gowing DJG, Hornibrook ERC, Davis JM, Dise NB (2010) Woody stem methane emission in mature wetland alder trees. Atmos Environ 44:2157-2160. https://doi.org/10.1016/j.atmosenv.2010.02.034

Gaveau DLA, Salim MA, Hergoualc'h K et al (2014) Major atmospheric emissions from peat fires in Southeast Asia during non-drought years: evidence from the 2013 Sumatran fires. Sci Rep 4:6112. https://oi. org/10.1038/srep06112

Gehring C, Denich M, Vlek PLG (2005) Resilience of secondary forest regrowth after slash-and-burn agriculture in central Amazonia. J Trop Ecol 21:519-527. https://doi.org/10.1017/S0266467405002543

Guariguata MR, Ostertag R (2001) Neotropical secondary forest succession: changes in structural and functional characteristics. For Ecol Manag 148:185-206. https://doi.org/10.1016/S0378-1127(00)00535-1

Gumbricht T, Roman-Cuesta RM, Verchot L, Herold M, Wittmann F, Householder E, Herold N, Murdiyarso D (2017) An expert system model for mapping tropical wetlands and peatlands reveals South America as the largest contributor. Glob Chang Biol 23:3581-3599. https://doi.org/10.1111/gcb.13689

Haase K, Rätsch G (2010) The morphology and anatomy of tree roots and their aeration strategies. In: Junk WJ et al. (eds) Amazonian floodplain forests: ecophysiology, biodiversity and sustainable management. Springer Netherlands, Dordrecht

Hergoualc'h K, Gutiérrez-Vélez VH, Menton M, Verchot LV (2017) Characterizing degradation of palm swamp peatlands from space and on the ground: an exploratory study in the Peruvian Amazon. For Ecol Manag 393: 63-73. https://doi.org/10.1016/j.foreco.2017.03.016

Hergoualc'h K, Verchot LV (2014) Greenhouse gas emission factors for land use and land-use change in Southeast Asian peatlands. Mitig Adapt Strateg Glob Chang 19:789-807. https://doi.org/10.1007/s11027-013-9511-X

Hergoualc'h K, Verchot LV (2011) Stocks and fluxes of carbon associated with land use change in southeast Asian tropical peatlands: a review. Glob Biogeochem Cycles 25. https://doi.org/10.1029/2009GB003718

Horn CM, Gilmore MP, Endress BA (2012) Ecological and socio-economic factors influencing aguaje (Mauritia flexuosa) resource management in two indigenous communities in the Peruvian Amazon. For Ecol Manag 267:93-103. https://doi.org/10.1016/j.foreco.2011.11.040 
Howard DM, Howard PJA (1993) Relationships between CO2 evolution, moisture content and temperature for a range of soil types. Soil Biol Biochem 25:1537-1546. https://doi.org/10.1016/0038-0717(93)90008-Y

Hoyos-Santillan J, Lomax BH, Large D, Turner BL, Boom A, Lopez OR, Sjögersten S (2015) Getting to the root of the problem: litter decomposition and peat formation in lowland Neotropical peatlands. Biogeochemistry 126:115-129. https://doi.org/10.1007/s10533-015-0147-7

Husen E, Salma S, Agus F (2014) Peat emission control by groundwater management and soil amendments: evidence from laboratory experiments. Mitig Adapt Strateg Glob Chang 19:821-829. https://doi.org/10.1007 /s11027-013-9526-3

Jauhiainen J, Hooijer A, Page SE (2012) Carbon dioxide emissions from an acacia plantation on peatland in Sumatra, Indonesia. Biogeosciences 9:617-630. https://doi.org/10.5194/bg-9-617-2012

Jauhiainen J, Silvennoinen H, Könönen M, Limin S, Vasander H (2016) Management driven changes in carbon mineralization dynamics of tropical peat. Biogeochemistry 129:115-132. https://doi.org/10.1007/s10533016-0222-8

Jauhiainen J, Takahashi H, Heikkinen JEP, Martikainen PJ, Vasander H (2005) Carbon fluxes from a tropical peat swamp forest floor. Glob Chang Biol 11:1788-1797. https://doi.org/10.1111/j.1365-2486.2005.01031.x

Jordan S, Velty S, Zeitz J (2007) The influence of degree of peat decomposition on phosphorus binding forms in fens. Mires and Peat 2:7

Kelly TJ, Baird AJ, Roucoux KH, Baker TR, Honorio Coronado EN, Ríos M, Lawson IT (2014) The high hydraulic conductivity of three wooded tropical peat swamps in northeast Peru: measurements and implications for hydrological function. Hydrological Processes 28:3373-3387. https://doi.org/10.1002/hyp.9884

Kluber HD, Conrad R (1998a) Inhibitory effects of nitrate, nitrite, NO and N2O on methanogenesis by Methanosarcina barkeri and Methanobacterium bryantii. FEMS Microbiol Ecol 25:331-339. https:/doi. org/10.1111/j.1574-6941.1998.tb00484.x

Kluber HD, Conrad R (1998b) Effects of nitrate, nitrite, NO and N2O on methanogenesis and other redox processes in anoxic rice field soil. FEMS Microbiol Ecol 25:301-318. https://doi.org/10.1111/j.15746941.1998.tb00482.x

Könönen M, Jauhiainen J, Laiho R et al (2015) Physical and chemical properties of tropical peat under stabilised land uses. Mires and Peat 16:8

Kreuzwieser J, Buchholz J, Rennenberg H (2003) Emission of methane and nitrous oxide by Australian mangrove ecosystems. Plant Biol 5:423-431. https://doi.org/10.1055/s-2003-42712

Kurnianto S, Warren M, Talbot J, Kauffman B, Murdiyarso D, Frolking S (2015) Carbon accumulation of tropical peatlands over millennia: a modeling approach. Glob Chang Biol 21:431-444. https://doi. org/10.1111/gcb.12672

Lähteenoja O, Ruokolainen K, Schulman L, Oinonen M (2009a) Amazonian peatlands: an ignored C sink and potential source. Glob Chang Biol 15:2311-2320. https://doi.org/10.1111/j.1365-2486.2009.01920.x

Lähteenoja O, Ruokolainen K, Schulman L, Alvarez J (2009b) Amazonian floodplains harbour minerotrophic and ombrotrophic peatlands. Catena 79:140-145. https://doi.org/10.1016/J.CATENA.2009.06.006

Linn DM, Doran JW (1984) Effect of water-filled pore space on carbon dioxide and nitrous oxide production in tilled and nontilled soils. Soil Sci Soc Am J 48:1267-1272. https://doi.org/10.2136 /sssaj1984.03615995004800060013x

Marengo J (1998) Climatología de la zona de Iquitos, Perú. In: Kalliola R, Flores Paitán S (eds) Geoecología y desarrollo amazónico: estudio integrado en la zona de Iquitos, Perú. Annales Universitatis Turkuensis Ser A II, vol 114. University of Turku, Finland, pp 35-57

Mathieu O, Lévêque J, Hénault C et al (2006) Emissions and spatial variability of N2O, N2 and nitrous oxide mole fraction at the field scale, revealed with $15 \mathrm{~N}$ isotopic techniques. Soil Biol Biochem 38:941-951. https://doi.org/10.1016/j.soilbio.2005.08.010

Melling L, Hatano R, Goh KJ (2005) Methane fluxes from three ecosystems in tropical peatland of Sarawak, Malaysia. Soil Biol Biochem 37:1445-1453. https://doi.org/10.1016/J.SOILBIO.2005.01.001

Minoda T, Kimura M (1994) Contribution of photosynthesized carbon to the methane emitted from paddy fields. Geophys Res Lett 21(18):2007-2010

Moore TR, Dalva M (1997) Methane and carbon dioxide exchange potentials of peat soils in aerobic and anaerobic laboratory conditions. Soil Biol Biochem 29:1157-1164

Moyano FE, Manzoni S, Chenu C (2013) Responses of soil heterotrophic respiration to moisture availability: an exploration of processes and models. Soil Biol Biochem 59:72-85. https://doi.org/10.1016/J. SOILBIO.2013.01.002

Murdiyarso D, Kauffman JB, Verchot LV (2013) Climate change mitigation strategies should include tropical wetlands. Carbon Manag 4:491-499. https://doi.org/10.4155/Cmt.13.46

Nilsson M, Bohlin E (1993) Methane and carbon dioxide concentrations in bogs and fens - with special reference to methane and carbon dioxide concentrations in bogs and fens -with special reference to the effects of the botanical composition of the peat. J Ecol 81:615-625 
Oktarita S, Hergoualc'h K, Anwar S, Verchot LV (2017) Substantial N2O emissions from peat decomposition and $\mathrm{N}$ fertilization in an oil palm plantation exacerbated by hotspots. Environ Res Lett 12(10):104007

Pacheco Santos LM (2005) Nutritional and ecological aspects of buriti or aguaje (Mauritia flexuosa Linnaeus filius): a carotene-rich palm fruit from Latin America. Ecol Food Nutr 44:345-358. https://doi.org/10.1080 /03670240500253369

Page SE, Rieley JO, Banks CJ (2011) Global and regional importance of the tropical peatland carbon pool. Glob Chang Biol 17:798-818. https://doi.org/10.1111/j.1365-2486.2010.02279.x

Page SE, Weiss D, Rieley JO et al (2004) A record of Late Pleistocene and Holocene carbon accumulation and climate change from an equatorial peat bog (Kalimantan, Indonesia): implications for past, present and future carbon dynamics. J Quat Sci 19:625-635. https://doi.org/10.1002/jqs.884

Pangala SR, Moore S, Hornibrook ERC, Gauci V (2013) Trees are major conduits for methane egress from tropical forested wetlands. New Phytol 197:524-531. https://doi.org/10.1111/nph.12031

Parton WJ, Scurlock JMO, Ojima DS, Gilmanov TG, Scholes RJ, Schimel DS, Kirchner T, Menaut JC, Seastedt T, Garcia Moya E, Kamnalrut A, Kinyamario JI (1993) Observations and modeling of biomass and soil organic matter dynamics for the grassland biome worldwide. Glob Biogeochem Cycles 7(4):785-809

Pihlatie M, Ambus P, Rinne J, Pilegaard K, Vesala T (2005) Plant-mediated nitrous oxide emissions from beech (Fagus sylvatica) leaves. New Phytol 168:93-98. https://doi.org/10.1111/j.1469-8137.2005.01542.x

Purvaja R, Ramesh R, Frenzel P (2004) Plant-mediated methane emission from an Indian mangrove. Glob Chang Biol 10:1825-1834. https://doi.org/10.1111/j.1365-2486.2004.00834.x

Roucoux KH, Lawson IT, Jones TD, Baker TR, Coronado ENH, Gosling WD, Lähteenoja O (2013) Vegetation development in an Amazonian peatland. Palaeogeogr Palaeoclimatol Palaeoecol 374:242-255. https://oi. org/10.1016/j.palaeo.2013.01.023

Ross DS, Ketterings Q (2011) Recommended methods for determining soil cation exchange capacity. In: Sims JT, Wolf A (eds) Recommended soil testing procedures for the northeastern United States, $3^{\text {rd }}$ edn. Agricultural Experiment Station, University of Delaware, Newark, USA

Roy R, Conrad R (1999) Effect of methanogenic precursors (acetate, hydrogen, propionate) on the suppression of methane production by nitrate in anoxic rice field soil. FEMS Microbiol Ecol 28:49-61. https://doi. org/10.1111/j.1574-6941.1999.tb00560.x

Ryan MG, Law BE (2005) Interpreting, measuring, and modeling soil respiration. Biogeochemistry 73:3-27

Schlesinger WH, Bernhardt ES (2013) The global carbon cycle. In: Schlesinger WH, Bernhardt ES (eds) Biogeochemistry: an analysis of global change, 3rd edn. Academic Press, Waltham, USA, pp 419-444

Smith K a, Ball T, Conen F et al (2003) Exchange of greenhousegases between soil and atmosphere: interactions of soil physical factors and biological processes. Eur J Soil Sci 54:779-791. https://doi.org/10.1046/j.13652389.2003.00567.x

Swails E, Jaye D, Verchot L, Hergoualc'h K, Schirrmann M, Borchard N, Wahyuni N, Lawrence D (2017) Will $\mathrm{CO} 2$ emissions from drained tropical peatlands decline over time? Links between soil organic matter quality, nutrients, and C mineralization rates. Ecosystems. https://doi.org/10.1007/s10021-017-0190-4

Teh YA, Murphy WA, Berrio J-C, Boom A, Page SE (2017) Seasonal variability in methane and nitrous oxide fluxes from tropical peatlands in the western Amazon basin. Biogeosciences 14:3669-3683. https://oi. org/10.5194/bg-14-3669-2017

Teh YA, Silver WL, Conrad ME (2005) Oxygen effects on methane production and oxidation in humid tropical forest soils. Glob Chang Biol 11:1283-1297. https://doi.org/10.1111/j.1365-2486.2005.00983.x

Tfaily MM, Cooper WT, Kostka JE, Chanton PR, Schadt CW, Hanson PJ, Iversen CM, Chanton JP (2014) Organic matter transformation in the peat column at Marcell experimental forest: humification and vertical stratification. J Geophys Res Biogeosci 119:661-675. https://doi.org/10.1002/2013JG002492

Updegraff K, Pastor J, Bridgham SD, Johnston CA (1995) Environmental and substrate controls over carbon and nitrogen mineralization in northern wetlands. Ecol Appl 5:151-163. https://doi.org/10.2307/1942060

van Lent J, Hergoualc'h K, Verchot LV (2015) Reviews and syntheses: soil $\mathrm{N}_{2} \mathrm{O}$ and $\mathrm{NO}$ emissions from land use and land-use change in the tropics and subtropics: a meta-analysis. Biogeosciences 12:7299-7313. https://doi.org/10.5194/bg-12-7299-2015

Van Noordwijk M, Martikainen P, Bottner P et al (1998) Global change and root function. Glob Chang Biol 4: 759-772. https://doi.org/10.1046/j.1365-2486.1998.00192.x

Verchot LV, Davidson EA, Cattânio JH, Ackerman IL (2000) Land-use change and biogeochemical controls of methane fluxes in soils of eastern Amazonia. Ecosystems 3:41-56. https://doi.org/10.1007/s100210000009

Virapongse A, Endress BA, Gilmore MP, Horn C, Romulo C (2017) Ecology, livelihoods, and management of the Mauritia flexuosa palm in South America. Glob Ecol Conserv 10:70-92. https://doi.org/10.1016/j. gecco.2016.12.005

Ziadi N, Sen Tran T (2007) Mehlich 3-extractable elements. In: Carter M, Gregorich E (eds) Soil sampling and methods of analysis, 2nd edn. Taylor \& Francis Group, Boca Raton, USA, pp 81-88 